\title{
Synthesis and characterization of $\mathrm{LiMn}_{1.5} \mathrm{Ni}_{0.5} \mathrm{O}_{4}$ powders using polymerization complex method
}

\author{
Jae-Ho Sin***, Jin-Ho Kim*, ${ }^{*}$, Hae-Jin Hwang**, Ung-Soo Kim* and Woo-Seok Cho* \\ *KICET Icheon Branch, Icheon 467-843, Korea \\ **Department of Ceramic Enginnering In-Ha University, Incheon 402-751, Korea \\ (Received July 11, 2012) \\ (Revised July 19, 2012) \\ (Accepted August 3, 2012)
}

\begin{abstract}
The $\mathrm{LiMn}_{1.5} \mathrm{Ni}_{0.5} \mathrm{O}_{4}$, substituting a part of $\mathrm{Mn}$ with $\mathrm{Ni}$ in the $\mathrm{LiMn}_{2} \mathrm{O}_{4}$, the spinel structure has good chargedischarge cycle stability and high discharge capacity at $4.7 \mathrm{~V}$. In this study $\mathrm{LiMn}_{1.5} \mathrm{Ni}_{0.5} \mathrm{O}_{4}$ powders were synthesized by polymerization complex method. The effect on the characteristics of synthesized $\mathrm{LiMn}_{1.5} \mathrm{Ni}_{0.5} \mathrm{O}_{4}$ powders was studied with citric acid (CA) : metal ion (ME) molar ratio $(5: 1,10: 1,15: 1,30: 1)$ and calcination temperature $\left(500 \sim 900^{\circ} \mathrm{C}\right)$. Single phase of $\mathrm{LiMn}_{1.5} \mathrm{Ni}_{0.5} \mathrm{O}_{4}$ was observed from XRD analysis on the powders calcined at low $\left(500^{\circ} \mathrm{C}\right)$ and high temperatures $\left(900^{\circ} \mathrm{C}\right)$. The crystalline size and crystallinity increased with calcination temperature. At low calcination temperature the particle size decreased and specific surface area increased as the CA molar ratio increased. On the other hand, high particle growth rate at high calcination temperature interfered the particle size reduction and specific surface area increase induced by the increase of CA molar ratio.
\end{abstract}

Key words Spinel, $\mathrm{LiMn}_{2} \mathrm{O}_{4}, \mathrm{LiMn}_{1.5} \mathrm{Ni}_{0.5} \mathrm{O}_{4}$, Polymerization complex method, Citric acid

\section{착체중합법을 이용한 $\mathrm{LiMn}_{1.5} \mathrm{Ni}_{0.5} \mathrm{O}_{4}$ 분말합성 및 특성평가}

신재호***, 김진호*;, 황해진**, 김응수*, 조우석*

*한국세라믹기술원 이천분원, 이천, 467-843

**인하대학교세라믹공학과, 인천, 402-751

(2012년 7월 11일 접수)

(2012년 7월 19일 심사완료)

(2012년 8월 3일 게재확정)

요 약 스피넬 구조로 이루어진 $\mathrm{LiMn}_{2} \mathrm{O}_{4}$ 에서 $\mathrm{Mn}$ 의 일부분을 $\mathrm{Ni}$ 로 치환한 $\mathrm{LiMn}_{1.5} \mathrm{Ni}_{0.5} \mathrm{O}_{4}$ 은 $4.7 \mathrm{~V}$ 전압 영역에서 높은 방전 용량 및 우수한 충 - 방전 사이클 특성을 가진다. 본 연구에서는 착체중합법을 이용하여 $\mathrm{LiMn}_{1.5} \mathrm{Ni}_{0.5} \mathrm{O}_{4}$ 를 합성하였다. Citric acid:metal의 몰비 $(5: 1,10: 1,15: 1,30: 1)$ 및 하소 온도 $\left(500 ~ 900^{\circ} \mathrm{C}\right)$ 변화에 따라 합성된 $\mathrm{LiMn}_{1.5} \mathrm{Ni}_{0.5} \mathrm{O}_{4}$ 분말의 특 성을 조사하였다. 합성된 분말의 $\mathrm{XRD}$ 분석을 통해 저온 $\left(500^{\circ} \mathrm{C}\right)$ 및 고온 $\left(900^{\circ} \mathrm{C}\right)$ 영역에서 모두 단일상인 $\mathrm{LiMn}_{1.5} \mathrm{Ni}_{0.5} \mathrm{O}_{4}$ 결 정상을 관찰할 수 있었고, 하소 온도가 증가함에 따라 결정화 및 결정자 크기도 함께 증가하였다. 합성된 $\mathrm{LiMn}_{1.5} \mathrm{Ni}_{0.5} \mathrm{O}_{4}$ 분 말의 형상 및 비표면적 분석 결과, 저온영역에서는 $\mathrm{CA}$ 몰비가 증가할수록 입자사이즈는 감소하고 비표면적은 증가하는 것 을 확인할 수 있었다. 반면에 고온영역에서는 온도 증가에 따른 입자 성장에너지가 CA 몰비 증가에 따른 입자 사이즈 감 소 및 비표면적 증가 효과를 감소시키는 것을 관찰하였다.

\section{1. 서 론}

최근 전자 산업의 눈부신 발전에 의해 스마트폰, 태블 릿 $\mathrm{PC}$ 등의 휴대용 전자 기기의 보급 증가와 $\mathrm{HEV}$,

\footnotetext{
Corresponding author

Tel: +82-31-645-1432

Fax: +82-31-645-1428

E-mail: hubyzzang@paran.com
}

$\mathrm{PHEV}, \mathrm{EV}$ 등의 연구가 활발히 진행되어 오고 있는 가 운데 고용량, 고출력 에너지 공급원인 리튬이온 이차전 지의 중요성이 점차 부각되고 있다. 현재 상용화 되고 있는 리틈이온 이차전지의 양극활 물질로는 층상구조인 $\mathrm{LiCoO}_{2}$ 가 있다. $\mathrm{LiCoO}_{2}$ 는 $\mathrm{Co}$ 의 높은 가격과 매장량의 한계 및 낮은 열적 안정성과 독성을 가지고 있으므로 이 를 대체할 물질로 스피넬 구조인 $\mathrm{LiMn}_{2} \mathrm{O}_{4}$ 와 층상 구조 인 $\mathrm{LiNiO}_{2}$ 의 연구가 활발히 진행되어 왔다[1-3]. 스피넬 
구조인 $\mathrm{LiMn}_{2} \mathrm{O}_{4}$ 는 풍부한 $\mathrm{Mn}$ 을 주 원료로 사용함으로 써 가격이 저렴하고, 친환경적이며 높은 열적 안정성을 가지고 있다. 반면에 낮은 용량과 실온보다 높은 온도에 서 $\mathrm{Mn}^{2+}$ 의 용출이 일어나 구조적으로 불안정 하며, $\mathrm{Li}$ 이온의 삽입과 탈리에 의해 $\mathrm{Mn}^{3+}$ 와 $\mathrm{Mn}^{4+}$ 가 서로 교체 하게 되고 이로 인해 정팔면체 위치에서의 Jahn-Teller distortion 현상이 발생하게 되어 사이클 안정성이 좋지 않은 문제점이 있다. 이러한 단점들을 개선하기 위하여 $\mathrm{Mn}$ 의 일부를 다른 전이금속으로 치환한 $\mathrm{LiM}_{x} \mathrm{Mn}_{2-x} \mathrm{O}_{4}$ $(\mathrm{M}=\mathrm{Co}, \mathrm{Mg}, \mathrm{Cr}, \mathrm{Ni}, \mathrm{Fe}, \mathrm{Al}, \mathrm{Ti}, \mathrm{Zn})$ 에 대한 연구가 선행되어 왔다[4-6]. 이러한 다른 전이금속으로 치환한 물질 중 $\mathrm{Ni}$ 로 치환하여 $4.7 \mathrm{~V}$ 전압의 영역에서 안정한 $\mathrm{Li}$ 이온의 삽입 및 탈리를 가능하게 하여 높은 방전 용량 및 우수한 방전 사이클 특성을 가지는 물질인 $\mathrm{LiMn}_{1.5} \mathrm{Ni}_{0.5} \mathrm{O}_{4}$ 의 연구가 활발히 진행되어 왔다[7, 8].

$\mathrm{LiMn}_{1.5} \mathrm{Ni}_{0.5} \mathrm{O}_{4}$ 를 합성하는 방법에는 주로 고상법, 졸 겔법, 수열합성법등을 이용하는데, 고상법의 경우 복잡한 공정 단계 및 반복되는 밀링(milling) 공정에 의해 여러 분순물이 유입되기 쉬운 단점이 있고, 수열합성 및 졸겔 법의 경우 다성분계 금속 성분을 가지는 분말의 화학 양 론적 조성을 유지하기 어려운 단점이 있다[9-13].

본 연구에서는 착체중합법(polymerized complex method) 을 이용하여 $\mathrm{LiMn}_{1.5} \mathrm{Ni}_{0.5} \mathrm{O}_{4}$ 을 합성하고자 한다. 착제중 합법은 초기 전구체 용액에서부터 금속 킬레이트착체를 형성하여 중합 반응을 통한 수지상 형성 및 최종 소결체 에 있어서도 화학양론적 조성의 균일성이 유지되기 때문 에 다성분계 세라믹 분말 합성에 매우 적합하며, 기존 세라믹 분말 합성법보다 매우 낮은 온도에서 합성이 가 능하며, 고상법에서 필요한 분쇄 및 재소결 단계가 필요 하지 않은 장점을 가지고 있다 $[11,14]$.

본 연구에서는 이러한 착체중합법을 이용하여 $\mathrm{CA}$ (citric $\mathrm{acid})$ 와 $\mathrm{ME}(\mathrm{metal})$ 의 몰비 및 하소온도를 변화시켜 합성 한 $\mathrm{LiMn}_{1.5} \mathrm{Ni}_{0.5} \mathrm{O}_{4}$ 분말의 형상과 크기, 결정화도 및 결정자 크기 등의 물리적 특성에 미치는 영향을 연구하 였다.

\section{2. 실험방법}

\section{1. $\mathrm{LiMn}_{1.5} \mathrm{Ni}_{0.5} \mathrm{O}_{4}$ 분말의 합성}

본 연구에서는 출발원료로 $\mathrm{Citric} \operatorname{acid}(\mathrm{HOC}(\mathrm{COOH})$ $\left(\mathrm{CH}_{2} \mathrm{COOH}\right)_{2}, 99.5 \%$, Daejung Chem), Ethylene glycol $\left(\mathrm{HOCH}_{2} \mathrm{CH}_{2} \mathrm{OH}, 99 \%+\right.$, Samchun Pure Chem), Lithium Carbonate $\left(\mathrm{Li}_{2} \mathrm{CO}_{3}, 98 \%\right.$, Yakuri), Manganese Chloride $\left(\mathrm{MnCl}_{2} \cdot 4 \mathrm{H}_{2} \mathrm{O}, 98 \%\right.$, Yakuri), Nickel Chloride Hexahydrate $\left(\mathrm{NiCl}_{2} \cdot 6 \mathrm{H}_{2} \mathrm{O}, 98 \%\right.$, Wako)을 사용하였다.
$\mathrm{CA}$ (citric acid) : $\mathrm{ME}$ (Metal)의 몰비, 유기물 분해 공정 유무 및 하소 온도 등을 실험공정 변수로 두고 $\mathrm{LiMn}_{1.5} \mathrm{Ni}_{0.5} \mathrm{O}_{4}$ 분말을 합성하였다. ethylene glycol $4 \mathrm{M}$ 에 citric acid $1 \mathrm{M}$ 을 넣고 $90^{\circ} \mathrm{C}$ 에서 $200 \mathrm{rpm}$ 의 속도로 1시간 동안 교반하여 용해시킨 후, $\mathrm{CA}$ (Citric Acid)와 $\mathrm{ME}(\mathrm{Metal})$ 의 몰비를 고려하여 화학 양론적으로 계산된 lithium carbonate를 첨가하여 용해시키고 거기에 manganese chloride와 nickel chloride hexahydrate를 차례로 첨가하 여 용해시켜 전구체를 제조하였다. 제조된 전구체를 $130^{\circ} \mathrm{C}$ 로 가열하고 5 시간 동안 $200 \mathrm{rpm}$ 의 속도로 교반하 여 에스터화 반응(esterification)으로 과량의 ethylene glycol를 제거 시켜 준 후, heating mantle서 $300^{\circ} \mathrm{C}$ 로 가열하고 2 시간 동안 유지하여 잔존해 있는 액체를 증 발시켜 검은 색상의 분말을 제조하였다. 제조된 분말에 잔존해 있는 유기물들을 제거하기 위해 $400^{\circ} \mathrm{C}$ 로 가열하 고 5 시간 동안 열처리(유기물 분해 공정)하였다. 이때 제조된 분말의 유기물 분해 공정 유무에 따라 각각 500 $900^{\circ} \mathrm{C}$ 에서 5 시간 동안 각각 하소함으로써 $\mathrm{LiMn}_{1.5} \mathrm{Ni}_{0.5} \mathrm{O}_{4}$ 의 단일상을 갖는 분말을 합성하였다. 본 연구의 실험 공정을 Fig. 1에 나타내었다. 합성된 $\mathrm{LiMn}_{1.5} \mathrm{Ni}_{0.5} \mathrm{O}_{4}$ 양 극활물질의 결정상, 결정화 및 결정자 크기를 확인하기 위하여 XRD(XRD, D/MAX 2500, Rigaku/Japan)를 이 용하여 회절피크를 분석하였다. $\mathrm{CuK \alpha}$ 의 X-ray를 이용 하였고, $10 \sim 80^{\circ}$ 의 범위에서 $5 \% \mathrm{~min}$ 속도로 측정하였다.

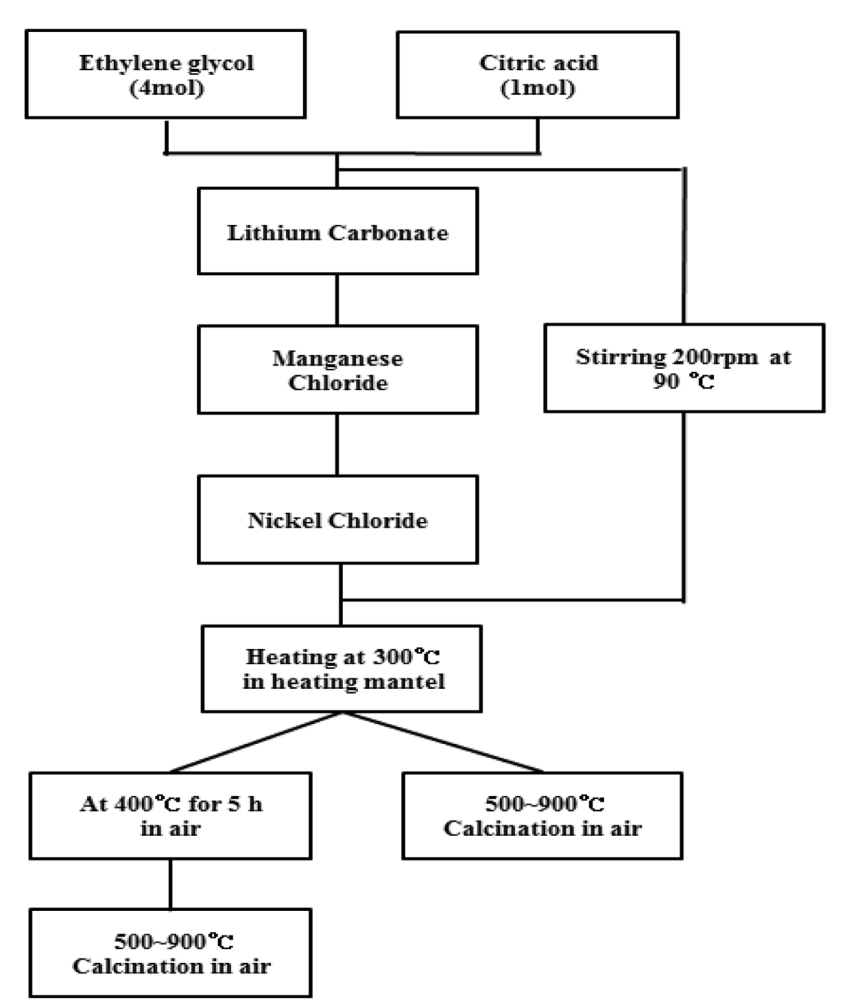

Fig. 1. Flow chart of polymerization complex process for $\mathrm{LiMn}_{1.5} \mathrm{Ni}_{0.5} \mathrm{O}_{4}$ synthesis. 
주사전자현미경(SEM, JSM-6701F, Jeol/Japan)을 이용하 여 합성된 $\mathrm{LiMn}_{1.5} \mathrm{Ni}_{0.5} \mathrm{O}_{4}$ 의 결정 형상과 입자의 크기 및 분포를 관찰하였다.

\section{3. 결과 및 고찰}

\section{1. 제조한 분말의 열적 거동 분석}

제조된 분말의 유기물 분해 온도와 $\mathrm{LiMn}_{1.5} \mathrm{Ni}_{0.5} \mathrm{O}_{4}$ 결정상 이 형성되는 온도를 관찰하기 위해 TG(Thermogravimetry)/ DTA(Differential Thermal Analysis) 분석을 하였다. Fig. 2는 착체중합법으로 합성한 분말의 열적 거동을 분석 한 결과이다. TG curve를 관찰해 보면 $320 ~ 450^{\circ} \mathrm{C}$ 영역에 서 급격한 무게 감소가 일어나는 것으로 보아 $\mathrm{Li}_{2} \mathrm{CO}_{3}$, $\mathrm{MnCl}_{2}, \mathrm{NiCl}_{2}$ 등이 열분해 되어 각각 $\mathrm{Li}_{2} \mathrm{O}, \mathrm{MnO}_{2}, \mathrm{NiO}_{2}$ 로 되는 과정, ethylene glycol의 증발, citric acid의 분해 및 유기물이 분해되어 연소가 일어나는 것으로 예측할 수 있다. DTA curve의 경우 $360^{\circ} \mathrm{C}$ 와 $410^{\circ} \mathrm{C}$ 영역에서 두 개 의 강한 발열 피크가 관찰되었다. 이는 $380 ~ 390^{\circ} \mathrm{C}$ 영역에 서는 제조된 분말에 잔존해 있는 유기물이 연소되어 증발 하는 온도 구간으로 예측할 수 있고, $410^{\circ} \mathrm{C}$ 에서의 발열 피크는 $\mathrm{LiMn}_{1.5} \mathrm{Ni}_{0.5} \mathrm{O}_{4}$ 결정상이 형성되는 온도로 추측된 다. 이러한 열분석 결과 $400^{\circ} \mathrm{C}$ 에서 유기물 분해 후 결정 상 $\mathrm{LiMn}_{1.5} \mathrm{Ni}_{0.5} \mathrm{O}_{4}$ 분말을 합성할 수 있는 온도로 $500^{\circ} \mathrm{C}$ 에 서부터 하소하는 것이 적합하다는 것을 알 수 있다.

\section{2. $\mathrm{LiMn}_{1.5} \mathrm{Ni}_{0.5} \mathrm{O}_{4}$ 분말의 특성 분석}

\subsection{1. 유기물 분해 유무 및 하소 온도에 따른 결정상}

Fig. 3, 4는 제조된 분말, 유기물 분해 $\left(400^{\circ} \mathrm{C}\right)$ 유무에

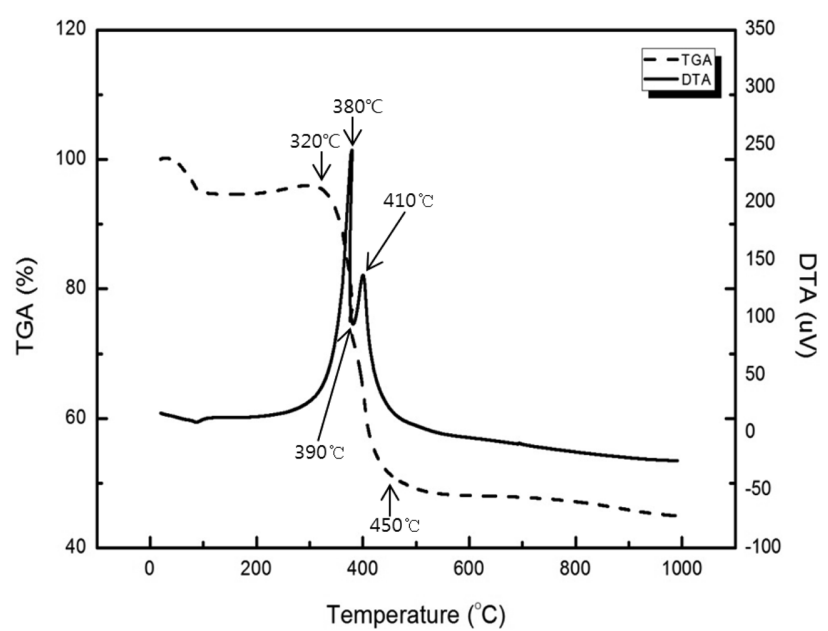

Fig. 2. TG-DSC curves of $\mathrm{LiMn}_{1.5} \mathrm{Ni}_{0.5} \mathrm{O}_{4}$ powders prepared via polymerization complex method.

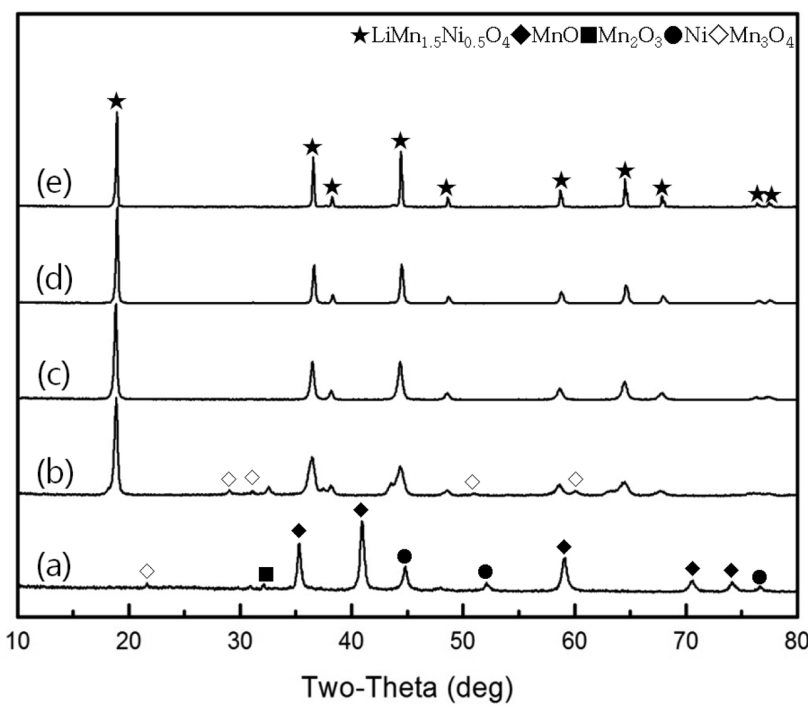

Fig. 3. XRD patterns of $\mathrm{LiMn}_{1.5} \mathrm{Ni}_{0.5} \mathrm{O}_{4}$ calcined at various temperatures after organic decomposition at $400^{\circ} \mathrm{C}$, (a) as-prepared powder, (b) $400^{\circ} \mathrm{C}$ (organic removal process), (c) $500^{\circ} \mathrm{C}$, (d) $700^{\circ} \mathrm{C}$, (e) $900^{\circ} \mathrm{C}$.

따라 하소하여 합성된 분말들의 결정상 분석 결과이다. 제조된 분말의 $\mathrm{XRD}$ 분석 결과, $\mathrm{LiMn}_{1.5} \mathrm{Ni}_{0.5} \mathrm{O}_{4}$ 상은 관 찰되지 않고 $\mathrm{MnO}, \mathrm{Mn}_{2} \mathrm{O}_{3}, \mathrm{Ni}, \mathrm{Mn}_{3} \mathrm{O}_{4}$ 등의 피크가 관 찰 된 것으로 보아, 제조된 분말에서는 $\mathrm{LiMn}_{1.5} \mathrm{Ni}_{0.5} \mathrm{O}_{4}$ 결정상이 형성되지 않았다는 알 수 있다. Fig. 3을 보면 제조된 분말의 유기물 분해 처리 후, $500 \sim 900^{\circ} \mathrm{C}$ 에서 하 소한 분말은 모든 몰비 및 하소 온도에서 단일상의 $\mathrm{LiMn}_{1.5} \mathrm{Ni}_{0.5} \mathrm{O}_{4}$ 가 생성되었음을 확인할 수 있다. Fig. 4는 유기물 분해 없이 하소한 분말들의 XRD 결정상 분석 결과로 $\mathrm{LiMn}_{1.5} \mathrm{Ni}_{0.5} \mathrm{O}_{4}$ 결정상은 관찰되지 않고 $\mathrm{MnO}$,

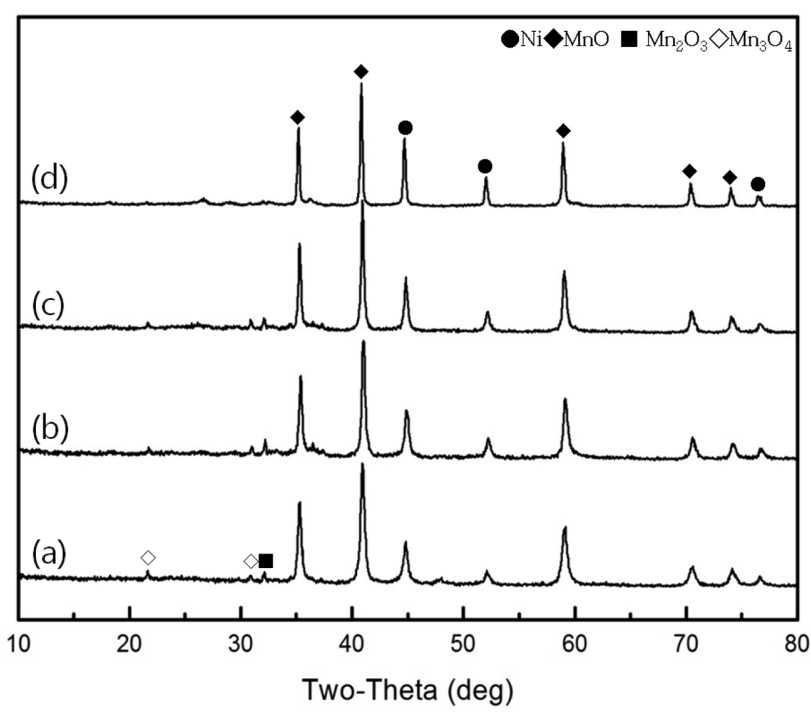

Fig. 4. XRD patterns of $\mathrm{LiMn}_{1.5} \mathrm{Ni}_{0.5} \mathrm{O}_{4}$ calcined at various temperatures without organic decomposition at $400^{\circ} \mathrm{C}$, (a) as-prepared powder, (b) $500^{\circ} \mathrm{C}$, (c) $700^{\circ} \mathrm{C}$, (d) $900^{\circ} \mathrm{C}$. 
$\mathrm{Mn}_{2} \mathrm{O}_{3}, \mathrm{Ni}, \mathrm{Mn}_{3} \mathrm{O}_{4}$ 등의 결정상이 관찰되는 것을 확인 할 수 있었다. 이러한 이유는 유기물이 완전히 분해되어 증발하지 않는 상태에서 열에너지를 받아 확산을 일으켜 안정한 스피넬 구조를 이루려는 $\mathrm{Li}, \mathrm{Mn}$ 원자들이 잔존 해 있는 유기물의 방해로 인하여 확산이 원활히 일어나 지 않아 $\mathrm{LiMn}_{1.5} \mathrm{Ni}_{0.5} \mathrm{O}_{4}$ 결정상을 형성하지 못하는 것으 로 추측할 수 있다[11]. 유기물 분해 후, 하소하여 합성 된 스피넬 구조의 $\mathrm{LiMn}_{1.5} \mathrm{Ni}_{0.5} \mathrm{O}_{4}$ 의 $\mathrm{XRD}$ 회절 패턴을 이용하여 격정상수(Lattice constant) a값을 계산한 결과, 모든 몰비 및 하소 온도에서 합성된 $\mathrm{LiMn}_{1.5} \mathrm{Ni}_{0.5} \mathrm{O}_{4}$ 분말 들의 격자상수는 8.12 8.16 ̊이었다. 이러한 결과는 $\mathrm{CA}: \mathrm{ME}$ 의 몰비 및 하소 온도가 격자상수에 미치는 효 과가 미미한 것을 확인할 수 있었다. 앞서 언급한 $\mathrm{TG}-$ $\mathrm{DSC}$ 분석 결과 $410^{\circ} \mathrm{C}$ 부근에 발생하는 발열 peak과 제 조된 분말의 유기물 분해 처리한 후 XRD 결정상 분석 결과에서 $\mathrm{LiMn}_{1.5} \mathrm{Ni}_{0.5} \mathrm{O}_{4}$ 상이 관찰되는 것으로 보아 약 $400^{\circ} \mathrm{C}$ 부근에서 $\mathrm{LiMn}_{1.5} \mathrm{Ni}_{0.5} \mathrm{O}_{4}$ 결정상이 형성되는 것을 알 수 있다.

\subsection{2. $\mathrm{CA}: \mathrm{ME}$ 몰비 및 하소 온도에 따른 미세구조}

Fig. 5 는 착체중합법에 의해 제조된 분말의 유기물 분 해 후, $700,800,900^{\circ} \mathrm{C}$ 에서 하소한 $\mathrm{LiMn}_{1.5} \mathrm{Ni}_{0.5} \mathrm{O}_{4}$ 분말 의 SEM사진이다. SEM사진으로부터 하소 온도가 상승 할수록 입자 크기는 점차적으로 증가하는 것을 관찰할 수 있다. $700 ~ 800^{\circ} \mathrm{C}$ 에서 하소한 입자 형상은 구형에 가 까우며 서브 마이크론 크기를 가지는 $\mathrm{LiMn}_{1.5} \mathrm{Ni}_{0.5} \mathrm{O}_{4}$ 입
자이었고, $900^{\circ} \mathrm{C}$ 에서 하소한 분말은 수 마이크론 크기의 다각형 형상을 가진 $\mathrm{LiMn}_{1.5} \mathrm{Ni}_{0.5} \mathrm{O}_{4}$ 입자이었다. Fig. 3(a), (b)와 (d), (e)를 관찰해 보면 $700 \sim 800^{\circ} \mathrm{C}$ 에서는 $\mathrm{CA}$ 의 몰 비가 증가할수록 입자 크기는 점차 감소하며, 입도 분포 는 균일해지는 것을 관찰할 수 있다. 이는 citric acid 몰 비 증가로 인해 많은 양의 citric acid의 carboxylic acid 기 체인 끝에 $\mathrm{Li}, \mathrm{Mn}, \mathrm{Ni}$ 등의 금속 이온들이 킬레이트 화 되어 균일하게 분포하는 현상이 증가하기 때문에 $\mathrm{CA}$ 몰비 증가에 따라 입도 분포 균질성 증가 및 입자 크기가 감소하는 것으로 생각된다. 하지만 $900^{\circ} \mathrm{C}$ 에서는 $\mathrm{CA}$ 몰비 증가에 따른 입자 크기 및 입도 분포 균질성 증가 효과가 감소하고 결정의 크기가 급격히 증가 하는 것을 알 수 있다. 이는 $900^{\circ} \mathrm{C}$ 의 경우 $\mathrm{CA}$ 몰비 증가에 따른 결정립 크기 감소 및 입도 분포 균질성 증가 효과 보다 하소 온도 상승에 따른 결정성장에 더 큰 영향을 미치는 것으로 판단된다.

\subsection{3. $\mathrm{CA}$ : $\mathrm{ME}$ 몰비 및 하소 온도에 따른 결정화}

리튬이차전지 양극 활물질에서 합성된 분말의 결정화 는 리튬 이온의 삽입 및 탈리 거동에 많은 영향을 주는 인자로 알려져 있다 $[14,15]$. 낮은 결정성을 가지는 양극 활물질의 경우 리튬 이온이 양극 활물질 결정 구조 내에 원활한 삽입 및 탈리 거동이 이루어지지 못하여 낮은 충 - 방전 사이클 특성을 가지기 때문에 리튬 이차 전지 의 양극 활물질의 결정화는 매우 중요하다. Fig. 6은 유 기물 분해 후, 하소 온도 및 $\mathrm{CA}: \mathrm{ME}$ 몰비의 변화에 따

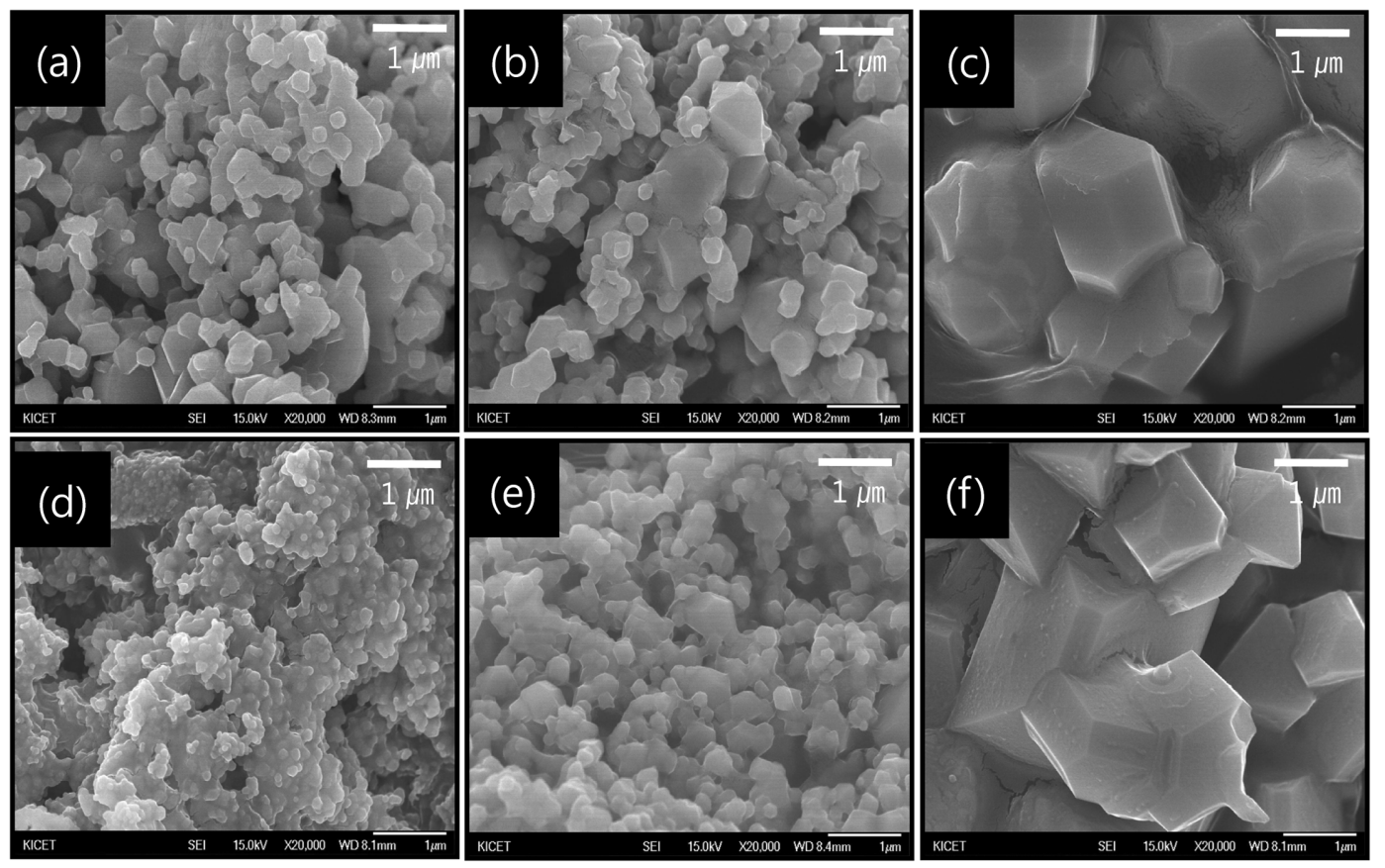

Fig. 5. SEM images of $\mathrm{LiMn}_{1.5} \mathrm{Ni}_{0.5} \mathrm{O}_{4}$ powders prepared via polymerization complex method, (a) $15: 1,700^{\circ} \mathrm{C}$, (b) $15: 1,900^{\circ} \mathrm{C}$, (c) $30: 1,700^{\circ} \mathrm{C}$, (d) $30: 1,900^{\circ} \mathrm{C}$. 


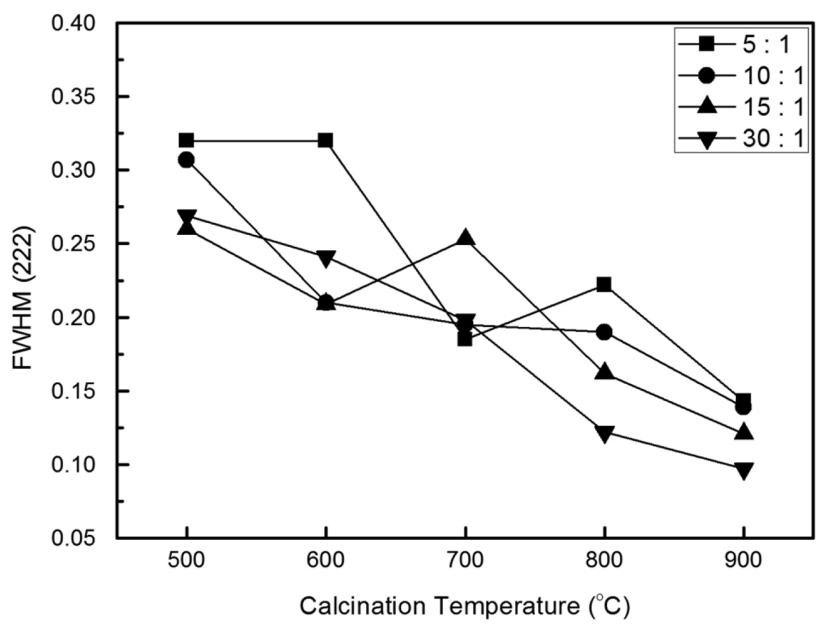

Fig. 6. Effect of calcination temperature and $\mathrm{CA}$ : ME molar ratio on the FWHM (222) of $\mathrm{LiMn}_{1.5} \mathrm{Ni}_{0.5} \mathrm{O}_{4}$.

라 합성된 $\mathrm{LiMn}_{1.5} \mathrm{Ni}_{0.5} \mathrm{O}_{4}$ 분말들의 $\mathrm{FWHM}$ (Full width half maximum)을 도식화한 그래프이다. Fig 6에서 하소 온도가 상승할수록 결정화가 점차적으로 높아지는 것을 관찰할 수 있다. 그러나 동일한 하소 온도에서 $\mathrm{CA}$ : $\mathrm{ME}$ 몰비 변화에 따른 결정화의 차이는 나타나지 않았 다. 이러한 경향은 하소 온도가 결정화에 큰 영향을 미 치는 요인인 것으로 판단된다.

\subsection{4. $\mathrm{CA}: \mathrm{ME}$ 몰비 및 하소 온도에 따른 결정자 크기}

리튬이온 이차전지에서 스피넬 구조를 가지는 양극 활 물질 내 리튬 이온 삽입과 탈리 거동은 Interstitial site 를 따라 이동하기 때문에 Interstitial space가 증가할수록 리튬 이온의 이동이 원활하게 된다. 결정자 크기가 증가 할 때 Interstitial space도 증가하기 때문에 스피넬 결정 구조를 가지는 $\mathrm{LiMn}_{1.5} \mathrm{Ni}_{0.5} \mathrm{O}_{4}$ 에서의 결정자 크기는 충 ·

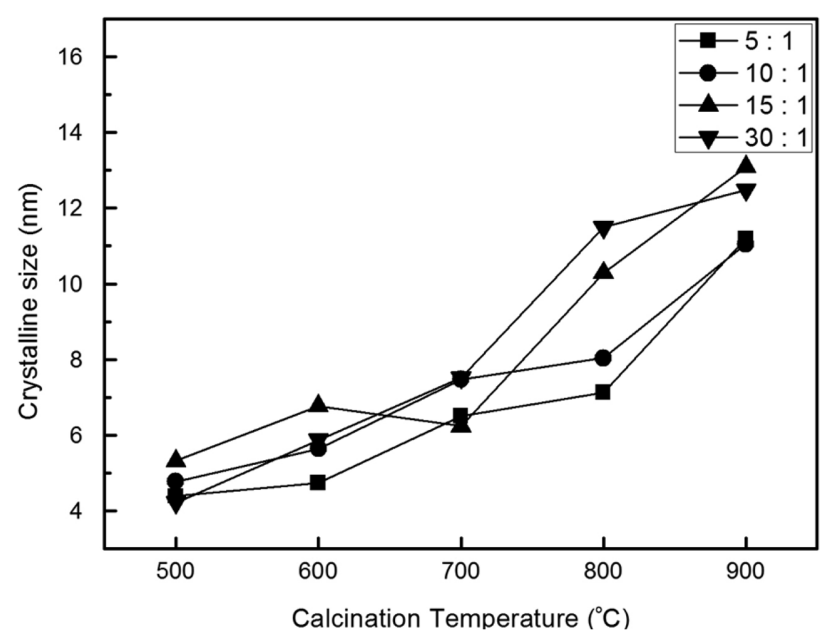

Fig. 7. Effect of calcination temperature and $\mathrm{CA}: \mathrm{ME}$ molar ratio on the crystalline size of $\mathrm{LiMn}_{1.5} \mathrm{Ni}_{0.5} \mathrm{O}_{4}$.
방전 사이클 특성에 매우 중요한 인자라고 할 수 있다 [16]. Fig. 7은 $\mathrm{CA}$ : $\mathrm{ME}$ 몰비 및 하소 온도에 따라 합성 된 $\mathrm{LiMn}_{1.5} \mathrm{Ni}_{0.5} \mathrm{O}_{4}$ 결정상의 (400)면 피크를 이용하여 결 정자 크기를 계산하여 나타낸 것이다. $\mathrm{CA}: \mathrm{ME}$ 몰비와 하소 온도에 따라 합성된 $\mathrm{LiMn}_{1.5} \mathrm{Ni}_{0.5} \mathrm{O}_{4}$ 분말의 결정자 크기를 계산하기 위하여 아래의 Scherer's equation을 이 용하여 계산하였다[17].

$$
\mathrm{D}=\frac{0.9 \lambda}{\beta \cos \theta}
$$

위의 공식에서 $\mathrm{D}$ 는 결정자 크기이고, $\lambda$ 는 파장(1.5406), $\beta$ 는 반가폭, $\theta$ 는 회절각도이다. Scherer's equation을 이 용하여 결정 사이즈를 계산한 결과, 하소 온도가 상승할 수록 하소 온도에 비례하여 결정 크기도 증가하였다. $500 \sim 700^{\circ} \mathrm{C}$ 에서는 $\mathrm{CA}$ 몰비 증가에 따른 결정자 크기 효 과는 나타나지 않았다. 그러나 $800 \sim 900^{\circ} \mathrm{C}$ 에서는 $\mathrm{CA}$ : $\mathrm{ME}$ 몰비가 $10: 1$ 에서 $15: 1$ 로 증가한 경우 결정자 크기 가 크게 증가하는 것을 관찰할 수 있었다.

이러한 결과는 $\mathrm{CA}$ 몰비보다 하소 온도가 결정자 사이 즈에 큰 영향을 미치는 요인인 것으로 판단할 수 있다.

\subsection{5. $\mathrm{CA}$ : $\mathrm{ME}$ 몰비 및 하소 온도에 따른 비표면적}

Fig. 8은 $\mathrm{CA}: \mathrm{ME}$ 몰비와 하소 온도에 따른 $\mathrm{BET}$ 비 표면적(specific surface area)을 측정하여 몰비와 하소 온도가 비표면적 값에 어떠한 영향을 미치는가에 대하여 관찰하였다. 스피넬 구조의 양극활물질에서 비표면적 $\left(\mathrm{m}^{2} / \mathrm{g}\right)$ 은 충 - 방전 용량, 사이클 특성 및 사이클 회수에 따른 용량 감소에 밀접한 영향을 미치는 인자로 알려져 있다[18]. 입자 크기가 감소할수록 비표면적 값 $\left(\mathrm{m}^{2} / \mathrm{g}\right)$ 은 점차적으로 증가하게 되므로 입자 크기와 비표면적 값은 밀접한 상관 관계가 있다. Fig. 8 을 보면 하소 온도가

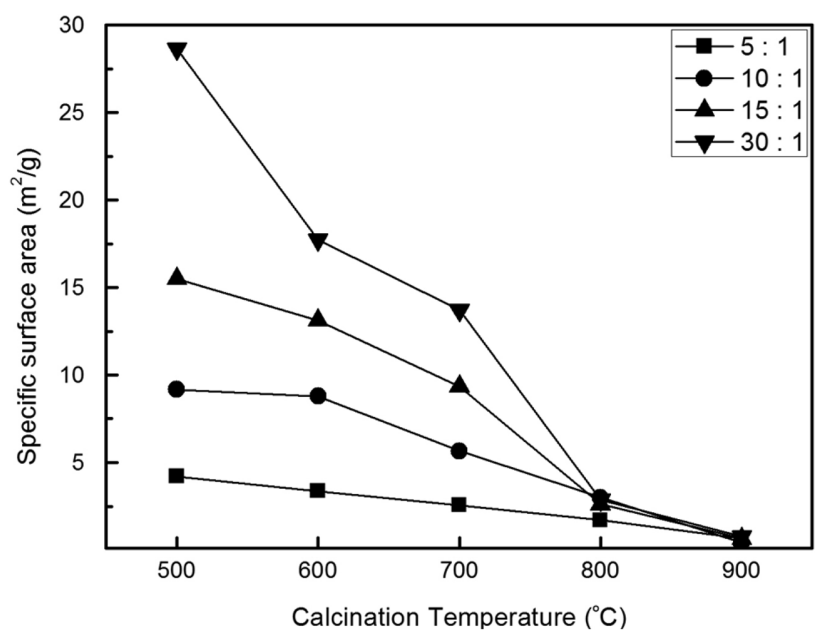

Fig. 8. Effect of calcination temperature and CA : ME molar ratio on the specific surface area of $\mathrm{LiMn}_{1.5} \mathrm{Ni}_{0.5} \mathrm{O}_{4}$. 
상승할수록 비표면적은 점차 감소하게 되며, $\mathrm{CA}$ 몰비가 증가할수록 비표면적은 점차 증가하는 것을 관찰할 수 있었고, 하소 온도가 상승할수록 $\mathrm{CA}$ 몰비에 증가에 따 른 입자 크기가 감소하는 효과가 점차 줄어드는 것을 확 인할 수 있었다. 이는 하소 온도가 점차 상승할수록 $\mathrm{CA}$ 몰비 증가에 따른 입자 크기 감소 효과보다 열에너지에 의해 결정상의 입자 성장에너지가 더 크기 때문인 것으 로 추측할 수 있다.

\section{4. 결 론}

착체중합법으로 제조한 분말은 저온영역 $\left(500^{\circ} \mathrm{C}\right)$ 에서 단 일상인 $\mathrm{LiMn}_{1.5} \mathrm{Ni}_{0.5} \mathrm{O}_{4}$ 가 합성되었다. 유기물 분해 없이 하소한 분말의 경우에는 잔존해 있는 유기물들이 안정한 스피넬 구조를 형성하는데 방해가 되어 $\mathrm{LiMn}_{1.5} \mathrm{Ni}_{0.5} \mathrm{O}_{4}$ 결정상은 생성되지 않았음을 확인할 수 있었다. 합성한 분말의 형상으로부터 하소 온도가 상승할수록 입자 크기 는 증가하고, $\mathrm{CA}$ 몰비가 증가함에 따라 입자 크기가 감 소하고 입도가 균일해 지는 것을 관찰할 수 있었다. 그 러나 고온 $\left(900^{\circ} \mathrm{C}\right)$ 에서는 $\mathrm{CA}: \mathrm{ME}$ 몰비에 대한 효과가 상쇄됨을 확인할 수 있었다. 합성된 $\mathrm{LiMn}_{1.5} \mathrm{Ni}_{0.5} \mathrm{O}_{4}$ 분말 들의 결정화도 및 결정자 크기를 분석한 결과 하소 온도 가 상승할수록 하소 온도에 비례하여 결정화도 및 결정 자 크기가 증가하는 것을 관찰하였다. 하소 온도가 상승 할수록 비표면적은 점차 감소하고, 같은 하소 온도에서 $\mathrm{CA}$ 몰비가 증가할수록 비표면적도 증가함을 확인하였다. 향후 $\mathrm{CA}: \mathrm{ME}$ 몰비 및 하소 온도에 변화에 따라 합성 된 $\mathrm{LiMn}_{1.5} \mathrm{Ni}_{0.5} \mathrm{O}_{4}$ 분말의 전기화학적 특성에 대한 연구 를 진행하여, $\mathrm{CA}: \mathrm{ME}$ 몰비 및 하소 온도 변화가 충· 방전 용량 및 사이클 특성 등의 전기화학적 특성에 어떠 한 영향을 미치는지를 분석하고자 한다.

\section{참 고 문 헌}

[1] R.J. Gummow, A. de Kock and M.M. Thackeray, "Improved capacity retention in rechargeable $4 \mathrm{~V}$ lithium manganese oxide (spinel) cells", Solid State Ionics 69 (1994) 59.

[2] M. Lanz, C. Kormann, H. Steininger, G. Heil, O. Haas and P. Novak, "Large-agglomerate-size lithium manganese oxide spinel with high rate capability for lithiumion batteries", J. Eletrochem. Soc. 147 (2000) 3997.

[ 3 ] J.R. Dahn, U. von Sacken and C.A. Michel, "Structure and electrochemistry of $\mathrm{Li}_{1 \pm y} \mathrm{NiO}_{2}$ and a new $\mathrm{Li}_{2} \mathrm{NiO}_{2}$ phase with the $\mathrm{Ni}(\mathrm{OH})_{2}$ structure," Solid State Ionics 44
(1990) 87.

[ 4 ] H.M. Wu, J.P. Tu, Y.F. Yuan, Y. Li, X.B. Zhao and G.S. Cao, "Electrochemical and ex situ XRD studies of a $\mathrm{LiMn}_{1.5} \mathrm{Ni}_{0.5} \mathrm{O}_{4}$ high-voltage cathode material", Electrochimica Acta 50 (2005) 4104.

[ 5 ] X. Wu and S.B. Kim, "Improvement of electrochemical properties of $\mathrm{LiMn}_{1.5} \mathrm{Ni}_{0.5} \mathrm{O}_{4}$ spinel", J. Power Sources 109 (2002) 53.

[6] G.T.K. Fey, C.Z. Lu and T.P. Kumar, "Preparation and electrochemical properties of high-voltage cathode materials, $\mathrm{LiM}_{\mathrm{y}} \mathrm{Ni}_{0.5 \mathrm{y}} \mathrm{Mn}_{1.5} \mathrm{O}_{4}(\mathrm{M} 1 / 4 \mathrm{Fe}, \mathrm{Cu}, \mathrm{Al}, \mathrm{Mg}$; y 1/4 0:00.4)", J. Power Sources 115 (2003) 332.

[ 7 ] L. Hernan, J. Morales, L. Sanchez and J. Santos, "Use of Li-M-Mn-O [M=Co, Cr, Ti] spinels prepared by a sol-gel method as cathodes in high-voltage lithium batteries", Solid State Ionics 118 (1999) 179.

[ 8 ] Q. Zhong, A. Bonakdarpour, M. Zhang, Y. Gao and J.R. Dahn, "Synthesis and electrochemistry of $\mathrm{LiNiMn}_{2-\mathrm{x}} \mathrm{O}_{4}$ ", J. Eletrochem. Soc. 144 (1997) 205.

[ 9 ] K. Amine, H. Tukamoto, H. Yasuda and Y. Fujita, "Preparation and electrochemical investigation of $\mathrm{LiMn}_{2-\mathrm{x}} \mathrm{Me}_{\mathrm{x}} \mathrm{O}_{4}$ (Me: $\mathrm{Ni}, \mathrm{Fe}$, and $\mathrm{x}=0.5,1$ ) cathode materials for secondary lithium batteries", J. Power Sources 68 (1997) 604.

[10] H.U. Kim, S.D. Youn, J.C. Lee, H.R. Park, C.G. Park and M.Y. Song, "Electrochemical properties of $\mathrm{LiNi}_{1-\mathrm{y}} \mathrm{In}_{\mathrm{y}} \mathrm{O}_{2}$ synthesized by milling and solid-state reaction method", Trans. of the Korean Hydrogen and New Energy Society 17 (2006) 117.

[11] S.M. Kim, S.H. Kim, J.H. Kim, U.S. Kim, H.J. Hwang and W.S. Cho, "Synthesis and electrochemical properties of $\mathrm{LiFePO}_{4}$ by citrate process", Trans. of the Korean Hydrogen and New Energy Society 22 (2011) 728.

[12] S. Yang, P.Y. Zavalij and M.S. Whittiugham, "Hydrothermal synthesis of lithium iron phosphate cathodes", Electrochem. Commun. 3 (2001) 505.

[13] M.A.E. Sanchez, G.E.S. Brito, M.C.A. Fantini, G.F. Goya and J.R. Matos, "Synthesis and characterization of $\mathrm{LiFePO}_{4}$ prepared by sol-gel technique", Solid State Ionics 177 (2006) 497.

[14] M.P. Pechini, United States Patent, 3, 330, 676, July (1967).

[15] A. Hitoshi, N. Koji, O. Nobuo and O. Takashi, "Effect of particle morphology on electrochemical property of $\mathrm{LiMn}_{2} \mathrm{O}_{4}$ ”, J. Ceram. Soc. (Japan) 109 (2001) 506.

[16] H. Huang, C.H. Chen, R.C. Perego, E.M. Kelder, L. Chen and J. Schoonman, "Electrochemical characterization of commercial lithium manganese oxide powders", Solid State Ionics 127 (2000) 31.

[17] E. Bulut, "Effect of calcination temperature on synthesis of $\mathrm{LiMn}_{2} \mathrm{O}_{4}$ cathod active nanoparticles for rechargeable Li-Ion batteries", Adv. Sci. Engin. Med. 3 (2011) 67.

[18] Y. Xia, N. Kumada and M. Yoshio, "Enhancing the elevated temperature performance of $\mathrm{Li} / \mathrm{LiMn}_{2} \mathrm{O}_{4}$ cells by reducing $\mathrm{LiMn}_{2} \mathrm{O}_{4}$ surface area", J. Power Sources 90 (2000) 135. 